\title{
Some Aspects of the Metabolism of Butyrivibrio fibrisolvens
}

\author{
By N. O. VAN GYLSWYK \\ National Chemical Research Laboratory, South African Council for Scientific and Industrial \\ Research - Onderstepoort Joint Unit for Research on Digestion and Metabolism in \\ Ruminants, P.O. Box 395, Pretoria, South Africa $000 \mathrm{I}$
}

(Received I6 March I976; revised I I June 1976)

\section{SUMMARY}

The growth responses of an acetate-utilizing isolate of Butyrivibrio fibrisolvens to $\mathrm{CO}_{2}$, acetate and pyruvate were determined using a chemically-defined medium. Carbon dioxide was essential for growth and both acetate and pyruvate increased growth. ${ }^{14} \mathrm{C}$ from $\left[{ }^{\mathrm{I}}{ }^{14} \mathrm{C}\right]$ acetate was found mainly in butyrate while ${ }^{14} \mathrm{C}$ from ${ }^{14} \mathrm{CO}_{2}$ or $\left[\mathrm{I}^{-14} \mathrm{C}\right]$ pyruvate appeared predominantly in formate and lactate. These results, together with those obtained with enzyme preparations, indicated pyruvate synthase, pyruvate- $\mathrm{CO}_{2}$ exchange and pyruvate formate lyase to be active.

\section{INTRODUCTION}

Butyrivibrio fibrisolvens can be, numerically, an important species in the rumen population, particularly in animals fed on high-roughage diets (Bryant et al., 1958; Gilchrist \& Kistner, I962; Gouws \& Kistner, I965; Caldwell \& Bryant, I966; van Gylswyk, 1970; Latham, Sharpe \& Sutton, I97I ; Latham, Storry \& Sharpe, I972). This paper extends the work done on B. fibrisolvens by Joyner \& Baldwin (1966) and Kistner \& Kotzé (1973), who measured activities of various enzymes.

Butyrivibrio fibrisolvens is considered to be the major butyric acid-producing species in the rumen (Bryant, 1970) and many butyrivibrio isolates, of the type placed in group I by Shane, Gouws \& Kistner (1969), utilize acetate in vitro. Since acetate is converted to butyrate in the rumen (Weller et al., 1967), one of the aims of the study was to establish whether a group I butyrivibrio is capable of effecting this conversion.

Bryant \& Small (1956) failed to find a $\mathrm{CO}_{2}$ requirement for a number of butyrivibrio isolates, but Gill \& King (I958) found an absolute requirement for $\mathrm{CO}_{2}$ in one group I isolate, and attributed the results of the former authors to their use of a test medium containing rumen fluid in which, despite efforts to remove it, enough bicarbonate might have remained to support growth. Van Gylswyk \& Roché (1970) failed to demonstrate a requirement of group I isolates for $\mathrm{CO}_{2}$ when using a medium containing rumen fluid. Another aim of the present work was to determine the $\mathrm{CO}_{2}$ requirements of an acetate-utilizing isolate and, if this existed, the incorporation of $\mathrm{CO}_{2}$ into the fermentation acids, butyrate, lactate and formate.

\section{METHODS}

Organism. The bacterium was isolate I2, characterized by van Gylswyk \& Roché (1970) as belonging to group $\mathrm{I}$ in the classification of Shane et al. (1969).

Media. The bacterium was maintained on slopes of agar medium containing rumen fluid and cellobiose (van Gylswyk \& Hoffman, 1970). The chemically-defined medium used in growth experiments was that of Roché et al. (1973) supplemented with glucose $\left(4.5 \mathrm{~g} \mathrm{l}^{-1}\right)$. 
This medium contained $\mathrm{NaHCO}_{3}\left(8 \mathrm{~g} \mathrm{l}^{-1}\right)$ and the gas phase was $98 \% \mathrm{CO}_{2} / 2 \% \mathrm{H}_{2}$. For the $\mathrm{CO}_{2}$-free medium, the bicarbonate and $\mathrm{CO}_{2}$ were omitted and the gas phase was $98 \%$ $\mathrm{N}_{2} / 2 \% \mathrm{H}_{2}$. Stimulatory effects of sodium acetate $\left(4 \cdot 1 \mathrm{~g} \mathrm{l}^{-1}\right)$ and sodium pyruvate $\left(5 \cdot 5 \mathrm{~g} \mathrm{l}^{-1}\right)$ were examined separately in media with and without $\mathrm{CO}_{2} /$ bicarbonate. The media were adjusted to $\mathrm{pH} 6 \cdot 8$. The distribution of ${ }^{14} \mathrm{C}$ from $\mathrm{CO}_{2}$, acetate and pyruvate was studied in basal medium with $\mathrm{CO}_{2}$ and bicarbonate, but with glucose increased to $\mathrm{IO}_{\mathrm{g} \mathrm{l}}{ }^{-1}$ and cysteine$\mathrm{HCl} . \mathrm{H}_{2} \mathrm{O}$ reduced to $250 \mathrm{mg} \mathrm{1^{-1 }}$.

The medium used for the production of bacteria for the enzyme tests contained (per litre): $\mathrm{KH}_{2} \mathrm{PO}_{4}, \mathrm{~K}_{2} \mathrm{HPO}_{4}$ and $\mathrm{NaCl}, 0.9 \mathrm{~g}$ of each; $\mathrm{CaCl}_{2}$ and $\mathrm{MgCl}_{2} .6 \mathrm{H}_{2} \mathrm{O}, 0.02 \mathrm{~g}$ of each ; $\mathrm{NaHCO}_{3}, 8 \mathrm{~g}$; $\left(\mathrm{NH}_{4}\right)_{2} \mathrm{SO}_{4}$, I.5 g; glucose, $10 \mathrm{~g}$; indigo carmine, $5 \mathrm{mg}$; cysteine$\mathrm{HCl} . \mathrm{H}_{2} \mathrm{O}$ and $\mathrm{Na}_{2} \mathrm{~S} .9 \mathrm{H}_{2} \mathrm{O}, 0.25 \mathrm{~g}$ of each; rumen fluid (clarified by centrifuging at $23000 \mathrm{~g}$ for $2 \mathrm{~h}$ ), $400 \mathrm{ml}$. The gas phase was $98 \% \mathrm{CO}_{2} / 2 \% \mathrm{H}_{2}$.

All media were sterilized by Millipore filtration, except that used for production of bacteria for enzyme tests : in this case the basal medium was heat sterilized, but solutions of glucose and reducing agent were separately sterilized by Millipore filtration and added to the cooled medium.

Anaerobic techniques. Anaerobic conditions were obtained by purging media and apparatus with $\mathrm{O}_{2}$-free gases containing about $2 \% \mathrm{H}_{2}$. The gases were passed through a 'Deoxo' catalyst cartridge (Engelhard Industries, London) to remove traces of $\mathrm{O}_{2}$. Inocula were transferred with sterile syringes. Incubation temperature was $38{ }^{\circ} \mathrm{C}$.

Effects of $\mathrm{CO}_{2}$, acetate and pyruvate on growth. Bacteria grown on three maintenance agar slopes for $22 \mathrm{~h}$ were collected, suspended in $8 \mathrm{ml} \mathrm{CO}_{2}$-free medium and portions $(0.2 \mathrm{ml})$ were used to inoculate each $10 \mathrm{ml}$ culture. Growth was measured directly as extinction $(578 \mathrm{~nm})$ in culture bottles ( $28 \mathrm{ml}$ McCartney bottles) which were previously matched. The length of the light path through the medium was about $23 \mathrm{~mm}$.

Incorporation of ${ }^{14} \mathrm{C}$ from $\left[\mathrm{I}^{-14} \mathrm{C}\right]$ acetate, $\mathrm{NaH}^{14} \mathrm{CO}_{3}$ and $\left[\mathrm{I}^{-14} \mathrm{C}\right]$ pyruvate into the fermentation acids by growing bacteria. Bacteria were grown in 50 or $100 \mathrm{ml}$ portions of medium inoculated with $0.5 \mathrm{ml}$ of a bacterial suspension (see above). The cultures were incubated for up to 5 days. Cells and slime were precipitated by adding $0.5 \mathrm{ml} 2.5 \mathrm{M}-\mathrm{H}_{2} \mathrm{SO}_{4}$ and shaking, and then I $\mathrm{ml} \mathrm{Io} \%(\mathrm{w} / \mathrm{v}) \mathrm{Na}_{2} \mathrm{WO}_{4} \cdot 2 \mathrm{H}_{2} \mathrm{O}$ solution per $10 \mathrm{ml}$ culture was added. The precipitate was compacted by centrifuging at $15000 \mathrm{~g}$ for $20 \mathrm{~min}$. Portions of the supernatant were alkalified and evaporated. The free acids were released by adding $2.5 \mathrm{M}^{-} \mathrm{H}_{2} \mathrm{SO}_{4}(2 \mathrm{ml})$; and acetic, butyric, lactic and formic acids in $0.5 \mathrm{ml}$ of the resulting solution were separated by silicic-acid column $(30 \times \mathrm{I} \mathrm{cm})$ chromatography using a method adapted from Ramsey ( 1963 ). Eluants (equilibrated with $0.25 \mathrm{M}-\mathrm{H}_{2} \mathrm{SO}_{4}$ ) were : benzene, $150 \mathrm{ml}$; chloroform, $100 \mathrm{ml}$; chloroform/t-butanol (99:I, v/v), $50 \mathrm{ml}$; chloroform/ t-butanol $(98: 2, v / v), 100 \mathrm{ml}$; chloroform/t-butanol $(92: 8, \mathrm{v} / \mathrm{v})$, I $50 \mathrm{ml}$. The eluates were collected in $8 \mathrm{ml}$ portions, titrated to $\mathrm{pH} 9$ with $0.0 \mathrm{I} \mathrm{M}-\mathrm{KOH}$ [in $90 \%(\mathrm{v} / \mathrm{v})$ ethanol] while mixing the contents of the tubes with a stream of nitrogen, then pooled, evaporated to a few $\mathrm{ml}$ and made up to $\mathrm{I} 0 \mathrm{ml}$; $\mathrm{I} \mathrm{ml}$ of this solution was added to $\mathrm{I} 5 \mathrm{ml}$ scintillation fluid (Braithwaite, Glascock \& Riazuddin, I969) and ${ }^{14} \mathrm{C}$ was estimated using a Packard TriCarb liquid scintillation spectrometer (model 3003). Corrections for quenching were made by the 'channels ratio' method.

Enzyme tests. Bacteria were grown until the $\mathrm{pH}$ of the medium reached $6 \cdot \mathrm{I}$, then cooled in ice water, harvested $(1600 \mathrm{~g} ; 25 \mathrm{~min})$, resuspended in anaerobic diluent (containing minerals, reducing agent and indigo carmine, and with the gas phase as for the growth medium) and reharvested. The resulting thick paste was purged with $98 \% \mathrm{CO}_{2} / 2 \% \mathrm{H}_{2}$ and stored in solid $\mathrm{CO}_{2}$. 
Bacteria were treated with toluene by mixing $7 \mathrm{ml}$ of the paste with $0.5 \mathrm{ml}$ toluene immediately before incubation.

Cell-free extracts were prepared under $98 \% \mathrm{~N}_{2} / 2 \% \mathrm{H}_{2}$. About $7 \mathrm{ml}$ of wet cells were thawed at room temperature, and then mixed with $2 \mathrm{ml}$ dithiothreitol $(0.05 \%)$, followed by I $\mathrm{ml}$ Tris buffer $(7 \cdot 27 \%$ w/v; $\mathrm{pH} 7 \cdot 6)$, I ml lysozyme $(0.4 \%)$ and I ml EDTA solution (disodium salt ; $4 \%, \mathrm{w} / \mathrm{v} ; \mathrm{pH} 7 \cdot 6$ ). The mixture was incubated at $39^{\circ} \mathrm{C}$ for $30 \mathrm{~min}$. Crude lysate $(7 \mathrm{ml})$ was disrupted ultrasonically (Soniprobe, type II30A; Dawe Instruments, London) for two I $5 \mathrm{~s}$ periods separated by $\mathrm{I}$ min for cooling, and centrifuged for $20 \mathrm{~min}$ at $35000 \mathrm{~g}$ at ${ }^{\circ} \mathrm{C}$. The supernatant was termed cell-free extract.

The enzyme reaction mixtures (Table 2 ) were incubated at $39^{\circ} \mathrm{C}(30 \mathrm{~min})$ and the reactions were stopped by immersion in boiling water (IO min). Unlabelled acetate (I $50 \mu \mathrm{mol}$ ), butyrate $(300 \mu \mathrm{mol})$, formate $(25 \mu \mathrm{mol})$ and lactate $(100 \mu \mathrm{mol})$, as carriers, were added before the alkaline mixtures were evaporated to dryness. The acids were separated on a silicic-acid column $(75 \times \mathrm{I} \mathrm{cm})$ using the following sequence of solvents : benzene, $50 \mathrm{ml}$; chloroform, I00 $\mathrm{ml}$; chloroform/t-butanol (99:I, v/v), I00 $\mathrm{ml}$; chloroform/t-butanol $(98: 2, \mathrm{v} / \mathrm{v}), \quad \mathrm{I} 50 \mathrm{ml}$; chloroform/t-butanol $(95: 5, \mathrm{v} / \mathrm{v}), \quad 100 \mathrm{ml}$; chloroform/t-butanol $(92: 8, v / v), 250 \mathrm{ml}$. The extent of incorporation of label into the different acids was estimated as described above.

Sources of biochemicals and labelled compounds. Biochemicals were from Boehringer, and the ${ }^{14} \mathrm{C}$-labelled compounds from The Radiochemical Centre, Amersham.

\section{RESULTS AND DISCUSSION}

Growth was rapidly initiated in media containing $\mathrm{NaHCO}_{3}$ plus $\mathrm{CO}_{2}$ (Fig. I). Both acetate and pyruvate stimulated growth, though pyruvate had a greater effect than acetate. In media free of $\mathrm{NaHCO}_{3}$ and $\mathrm{CO}_{2}$, there was an extended lag :acetate stimulated growth more than pyruvate but almost no growth occurred without acetate or pyruvate. The low rate of growth in $\mathrm{CO}_{2}$-free media may be due to a slow endogenous production of $\mathrm{CO}_{2}$ by the inoculum.

When incorporation of ${ }^{14} \mathrm{C}$ from media containing $\left[\mathrm{I}{ }^{14} \mathrm{C}\right]$ acetate, $\mathrm{NaH}^{14} \mathrm{CO}_{3}$ or $\left[\mathrm{I}^{-14} \mathrm{C}\right]$ pyruvate into acetate, butyrate, formate and lactate by growing cells was followed (Table I), butyrate was found to be extensively labelled from acetate, showing that extracellular acetate is a precursor of butyrate. The recovery of label in the fermentation acids was $87 \%$ while $6 \%$ was retained on the silicic acid column. The remainder was probably incorporated into cells but was not measured. Butyrate was formed from both acetate supplied and acetate produced from glucose, because the molar specific activity of butyrate was less than twice that of the acetate supplied. The labelling of lactate from acetate suggests the existence of a pyruvate synthase system (Bachofen, Buchanan \& Arnon, I964). Label in formate cannot arise from the hydroclastic splitting of $\left[2-{ }^{14} \mathrm{C}\right]$ pyruvate produced from $\left[\mathrm{I}^{-14} \mathrm{C}\right]$ acetate by pyruvate synthase, since formate would come from C-I of pyruvate. Hence formate must be formed from acetate by other means. When the specific activities of acetate and lactate are compared it appears that about half the lactate was due to pyruvate synthesis. An amount of $\mathrm{CO}_{2}$ equivalent to that of acetate must have been used to produce pyruvate. Thus the extent of $\mathrm{CO}_{2}$ fixation is appreciable.

Label from $\mathrm{NaH}^{14} \mathrm{CO}_{3}$ appeared mostly in formate and lactate thus providing further evidence for activity of pyruvate synthase. Specific activities of formate and lactate were similar and so these acids could have been derived from the same pyruvate pool. A small amount of label appeared in acetate and butyrate. Preliminary work had shown that a small 


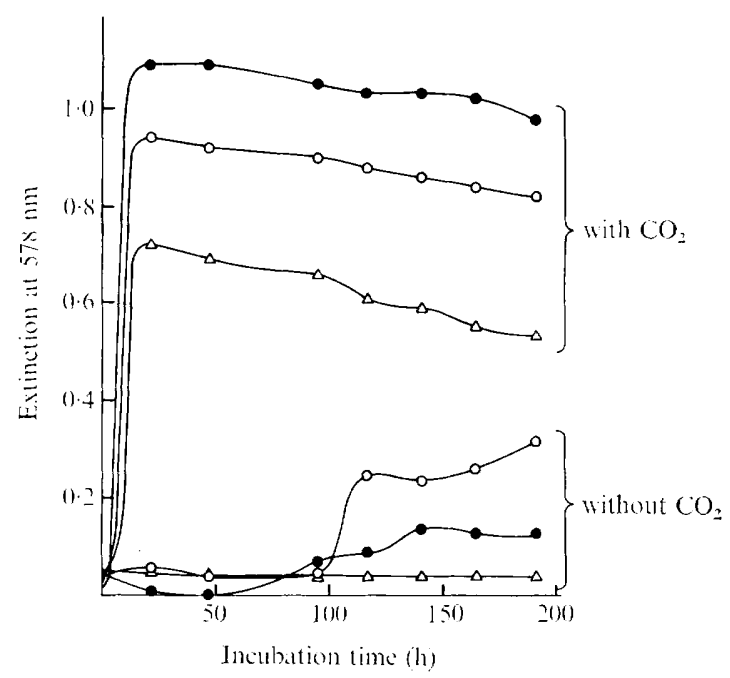

Fig. I. Growth of Butyrivibrio fibrisolvens (isolate 12 ) in defined medium containing glucose $(\triangle)$, glucose and acetate $(O)$, or glucose and pyruvate $(\bullet)$, each in the presence or absence of $\mathrm{CO}_{2}$. Acetate and pyruvate were equimolar.

Table I. Recovery of acids and incorporation of ${ }^{14} \mathrm{C}$ from $\left[\mathrm{I}^{-14} \mathrm{C}\right]$ acetate, $\mathrm{NaH}^{14} \mathrm{CO}_{3}$ or $\left[\mathrm{I}^{14} \mathrm{C}\right]$ pyruvate into these acids by $B$. fibrisolvens (isolate $\left.\mathrm{I} 2\right)$ grown in chemically-defined medium containing $0.8 \% \mathrm{NaHCO}_{3}$ and $\mathrm{I} \%$ glucose with a gas phase of $98 \% \mathrm{CO}_{2} / 2 \% \mathrm{H}_{2}$

\begin{tabular}{|c|c|c|c|}
\hline \multirow[b]{2}{*}{ Acids recovered } & \multicolumn{3}{|c|}{ Additions per $100 \mathrm{ml}$ medium } \\
\hline & $\begin{array}{c}10 \mathrm{mmol} \\
\mathrm{Na}\left[\mathrm{I}^{14} \mathrm{C}\right] \text { acetate* }\end{array}$ & $\begin{array}{c}\mathrm{NaH}^{14} \mathrm{CO}_{3} \dagger+ \\
5 \mathrm{mmol} \mathrm{Na} \text { acetate }\end{array}$ & $\begin{array}{c}5 \mathrm{mmol} \\
\mathrm{Na}\left[\mathrm{I}-{ }^{14} \mathrm{C}\right] \text { pyruvate }\end{array}$ \\
\hline $\begin{array}{l}\text { Acetate }(\mathrm{mmol} / \mathrm{I} 00 \mathrm{ml} \text { culture }) \\
\qquad\left(10^{-2} \times \text { d.p.m. } / \mathrm{mmol}\right)\end{array}$ & $\begin{array}{c}7 \cdot 36 \\
(2 \cdot 64 \text { utilized) } \\
6788\end{array}$ & $\begin{array}{c}3 \cdot 29 \\
(\mathrm{I} \cdot 7 \mathrm{I} \text { utilized }) \\
182\end{array}$ & $\begin{array}{r}2 \cdot 92 \\
248\end{array}$ \\
\hline $\begin{array}{l}\text { Butyrate (mmol// } 100 \mathrm{ml} \text { culture }) \\
\quad\left(10^{-2} \times \text { d.p.m. } / \mathrm{mmol}\right)\end{array}$ & $\begin{array}{r}2 \cdot 76 \\
1355 \mathrm{I}\end{array}$ & $\begin{array}{r}2 \cdot 36 \\
96\end{array}$ & $\begin{array}{r}1 \cdot 06 \\
147\end{array}$ \\
\hline $\begin{array}{l}\text { Formate }(\mathrm{mmol} / 100 \mathrm{ml} \text { culture }) \\
\qquad\left(\mathrm{I} 0^{-2} \times \text { d.p.m. } / \mathrm{mmol}\right)\end{array}$ & $\begin{array}{r}\mathrm{I} \cdot \mathrm{I} 8 \\
847\end{array}$ & $\begin{array}{r}I \cdot 43 \\
\text { I } 197\end{array}$ & $\begin{array}{r}0.66 \\
1046\end{array}$ \\
\hline $\begin{array}{l}\text { Lactate }(\mathrm{mmol} / \mathrm{I} 00 \mathrm{ml} \text { culture }) \\
\quad\left(\mathrm{I}^{-2} \times \text { d.p.m./mmol }\right)\end{array}$ & $\begin{array}{r}1 \cdot 46 \\
3236\end{array}$ & $\begin{array}{l}2 \cdot 28 \\
\mathrm{I} O 7 \mathrm{I}\end{array}$ & $\begin{array}{r}6 \cdot 89 \\
811\end{array}$ \\
\hline
\end{tabular}

Final specific activities: ${ }^{*} 10712 \times 10^{2}$ d.p.m. $/ \mathrm{mmol} ; \dagger$ not determined $(6 \mu \mathrm{Ci} / \mathrm{IOO} \mathrm{ml}) ; \$ 8632 \times 10^{2}$ d.p.m./mmol.

amount of $\mathrm{CO}_{2}$ could be included in the acetate peak despite acidification with strong acid, but label in the butyrate fraction shows that some $\mathrm{CO}_{2}$ must have been incorporated into acetate. This result, together with the finding that label from $\left[\mathrm{I}^{-14} \mathrm{C}\right]$ acetate enters formate, suggests that $\mathrm{CO}_{2}$ exchanges with the carboxyl group of acetate (Ljungdahl \& Wood, 1969). ${ }^{14} \mathrm{CO}_{2}$ so derived from $\left[{ }^{\mathrm{I}}{ }^{14} \mathrm{C}\right]$ acetate could enter pyruvate and thence formate.

When pyruvate replaced acetate in the medium the proportions of the fermentation acids were changed. Although pyruvate appeared to be converted mainly to lactate, the specific activity of lactate was only about $10 \%$ of that of the added pyruvate. This could have been due to dilution of exogenous with endogenously produced pyruvate, but the possible production of pyruvate from the available glucose was calculated to be too low 
Table 2. Percentage recovery of ${ }^{14} \mathrm{C}$ in acetate, butyrate, formate and lactate when cell-free extract of B. fibrisolvens (isolate I2) was incubated with ${ }^{14} C$-labelled pyruvate, bicarbonate or acetyl-CoA

The reaction mixtures contained : Cell-free extract pretreated with lysozyme and EDTA, $3 \mathrm{ml}$; dithiothreitol, Io $\mathrm{mg}$; deionized water, to $5.5 \mathrm{ml}$; plus either (i) $\mathrm{Na}\left[\mathrm{I}^{-1}{ }^{14} \mathrm{C}\right]$ pyruvate, $4 \mu \mathrm{mol}$ $(0.2 \mu \mathrm{Ci})$; CoA, I $\mu \mathrm{mol}$; phosphotransacetylase, $2 \mathrm{u}$.; $\mathrm{Na}$ glyoxylate $. \mathrm{H}_{2} \mathrm{O}, 4 \mu \mathrm{mol}$; $\mathrm{Na}$ arsenate, Io $\mu \mathrm{mol}$; or (ii) $\mathrm{NaH}^{14} \mathrm{CO}_{3}, 2 \mu \mathrm{mol}$ (I $\mu \mathrm{Ci}$ ); acetyl-CoA, $2 \mu \mathrm{mol}$; or (iii) [ $\left.{ }^{1-14} \mathrm{C}\right]$ acetyl-CoA, $2 \mu \mathrm{mol}(\mathrm{I} \mu \mathrm{Ci}) ; \mathrm{NaHCO}_{3}, 2 \mu \mathrm{mol} ; \mathrm{NADH}, 2 \mu \mathrm{mol}$. The gas phase was $\mathrm{H}_{2}$.

$\begin{array}{lccc}\text { Acids } & \text { (i) } \mathrm{Na}\left[\mathrm{I}-{ }^{14} \mathrm{C}\right] \text { pyruvate } & \text { (ii) } \mathrm{NaH}^{14} \mathrm{CO}_{3} & \text { (iii) }\left[\mathrm{I}-{ }^{14} \mathrm{C}\right] \text { acetyl-CoA } \\ \text { Acetate } & 0 & 0 & 9 \mathrm{I} \cdot 6 \\ \text { Butyrate } & 0 & 0 & 5.6 \\ \text { Formate } & 8 \cdot 7 & 0 & 0 \\ \text { Lactate } & 12 \cdot 2 & 0 & 0\end{array}$

Table 3. Recovery of ${ }^{14} C$ in the acids produced by B. fibrisolvens (isolate 12 ) treated with toluene and incubated with $\mathrm{NaH}^{14} \mathrm{CO}_{3}$ and an acetyl-CoA regenerating system or $\mathrm{NaH}^{14} \mathrm{CO}_{3}$ and pyruvate

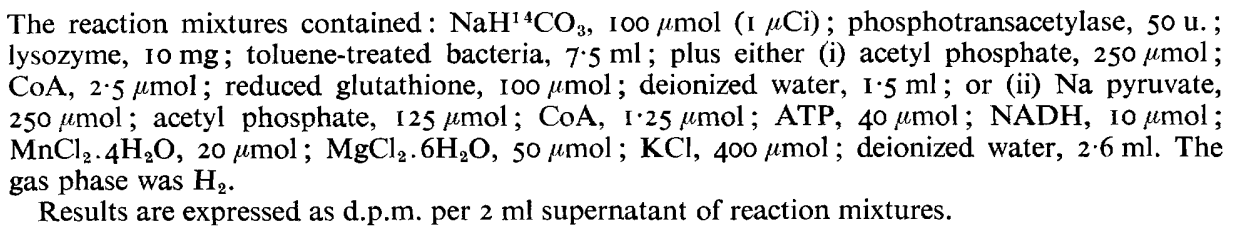

$\begin{array}{lcc}\text { Acids } & \begin{array}{c}\text { (i) } \mathrm{NaH}^{14} \mathrm{CO}_{3} \text { plus } \\ \text { acetyl-CoA regenerating system }\end{array} & \begin{array}{c}\text { (ii) } \mathrm{NaH}^{14} \mathrm{CO}_{3} \text { plus } \\ \text { pyruvate }\end{array} \\ \text { Acetate } & 8 \text { Io } & 949 \\ \text { Butyrate } & 3 \mathrm{I} 8 & 592 \\ \text { Formate } & 498 & \mathrm{I} 8 \mathrm{I} 3 \\ \text { Lactate } & 320 & 7703 \\ \text { Recovery }(\%) & \mathrm{I} \cdot 3 & 7.3\end{array}$

to explain the discrepancy. The exchange of $\mathrm{CO}_{2}$ with the carboxyl group of pyruvate seemed more likely and is characteristic of systems in which pyruvate synthesis occurs (Buchanan \& Arnon, I969). The labelled $\mathrm{CO}_{2}$ released could have exchanged with the carboxyl group of acetate giving the small amount of label which was again found in acetate and butyrate.

Extracts catalysed the reduction of pyruvate to lactate (Table 2) in the absence of added NADH or NADPH. Joyner \& Baldwin (1966) and Kistner \& Kotzé (1973) found very low activities for lactic dehydrogenase in extracts of $B$. fibrisolvens despite the fact that this species produces lactate. This could mean that pyruvate reduction depends on an electron carrier other than NADH or NADPH.

Extracts contained the enzymes necessary for the synthesis of butyrate from acetate (Table 2). However, no label from $\mathrm{NaH}^{14} \mathrm{CO}_{3}$ was found in any of the fermentation acids, showing the absence of pyruvate synthase. The mechanisms responsible for inclusion of ${ }^{14} \mathrm{C}$ from ${ }^{14} \mathrm{CO}_{2}$ into acetate and from $\left[\mathrm{I}^{-14} \mathrm{C}\right]$ acetate into formate were also absent. No incorporation of ${ }^{14} \mathrm{CO}_{2}$ into formate would indicate the absence of formate dehydrogenase (Thauer, Rupprecht \& Jungermann, 1970). The formation of $\mathrm{H}^{14} \mathrm{COOH}$ from $\left[\mathrm{I}^{14} \mathrm{C}\right]$ pyruvate must thus have been due to pyruvate formate lyase activity. This is contrary to the conclusions of Miller (1975, and personal communication) who failed to detect incorpora- 
tion of ${ }^{14} \mathrm{C}$ from $\mathrm{H}^{14} \mathrm{COOH}$ into pyruvate by extracts of $B$. fibrisolvens and hence concluded that formate is produced by direct reduction of $\mathrm{CO}_{2}$.

Toluene-treated bacteria showed pyruvate synthase activity (Table 3 ). This result suggests that pyruvate synthesis is catalysed by an insoluble fraction. In this, $B$. fibrisolvens must differ from other rumen organisms because Emmanuel \& Milligan (1973) found pyruvate synthase in extracts of mixed rumen microorganisms. The toluene-treated bacteria also incorporated ${ }^{14} \mathrm{C}$ from ${ }^{14} \mathrm{CO}_{2}$ into acetate and butyrate. It was thought possible that the carbon from $\mathrm{CO}_{2}$ might enter acetate via pyruvate carboxylation and the reductive carboxylic acid cycle (Evans, Buchanan \& Arnon, 1966). Accordingly, toluene-treated bacteria were also incubated with ${ }^{14} \mathrm{CO}_{2}$ and unlabelled pyruvate. This led to extensive labelling of lactate (Table 3) which again pointed to exchange of $\mathrm{CO}_{2}$ with the carboxyl group of pyruvate. The increased incorporation of $\mathrm{CO}_{2}$ into $\mathrm{HCOOH}$ in the presence of pyruvate provides additional evidence that it is formed via pyruvate formate lyase and not formate dehydrogenase. The test was repeated with avidin added to the reaction mixture so that biotin, a cofactor of pyruvate carboxylase, would be inactivated. This did not reduce the extent of labelling of acetate and butyrate. Hence it seems that label from ${ }^{14} \mathrm{CO}_{2}$ does not enter acetate by way of the reductive carboxylic acid cycle.

The author wishes to thank Dr H. M. Schwartz and Dr P. N. Hobson for their criticism of the manuscript.

\section{REFERENCES}

BaChofen, R., Buchanan, B. B. \& ARnon, D. I. (1964). Ferredoxin as a reductant in pyruvate synthesis by a bacterial extract. Proceedings of the National Academy of Sciences of the United States of America $\mathbf{5} \mathbf{r}$, 690-694.

Braithwaite, G. D., Glascock, R. F. \& Riazuddin, S. (1969). Calcium metabolism in lactating ewes. British Journal of Nutrition 23, 827-834.

BRyant, M. P. (1970). Normal flora-rumen bacteria. American Journal of Clinical Nutrition 23, I440-1450.

Bryant, M. P. \& SMAll, N. (1956). The anaerobic monotrichous butyric acid-producing curved rod-shaped bacteria of the rumen. Journal of Bacteriology 72, 16-21.

Bryant, M. P., Small, N., Bouma, C. \& Robinson, I. M. (1958). Studies on the composition of the ruminal flora and fauna of young calves. Journal of Dairy Science 4I, 1747-1 767.

Buchanan, B. B. \& ARnon, D. I. (1969). The reductive carboxylic acid cycle. Methods in Enzymology I3, I70-181.

CALDWELl, D. R. \& BRYANT, M. P. (I966). Medium without rumen fluid for nonselective enumeration and isolation of rumen bacteria. Applied Microbiology r4, 794-80I.

Emmanuel, B. \& Milligan, L. P. (1973). Reductive carboxylation of acetyl phosphate by cell-free extracts of mixed rumen micro-organisms. Journal of General Microbiology 77, 537-539.

Evans, M. C. W., Buchanan, B. B. \& Arnon, D. I. (1966). A new ferredoxin-dependent carbon reduction cycle in a photosynthetic bacterium. Proceedings of the National Academy of Sciences of the United States of America 55, 928-934.

Gilchrist, F. M. C. \& KISTNER, A. (I962). Bacteria of the ovine rumen. I. The composition of the population on a diet of poor teff hay. Journal of Agricultural Science 59, 77-83.

GILL, J. W. \& KING, K. W. (1958). Nutritional characteristics of a butyrivibrio. Journal of Bacteriology 75 , 666-673.

Gouws, L. \& Kistner, A. (1965). Bacteria of the ovine rumen. IV. Effect of change of diet on the predominant type of cellulose-digesting bacteria. Journal of Agricultural Science 64, 5 I-57.

GYLSWYK, N. O. VAN (1970). The effect of supplementing a low-protein hay on the cellulolytic bacteria in the rumen of sheep and on the digestibility of cellulose and hemicellulose. Journal of Agricultural Science, Cambridge 74, I69-180.

GYLSWYK, N. O. VAN \& Hoffman, J. P. L. (1970). Characteristics of cellulolytic cillobacteria from the rumens of sheep fed teff (Eragrostis tef) hay diets. Journal of General Microbiology 6o, $38 \mathrm{I}-386$.

GYLSWYK, N. O. VAN \& RochÉ, C. E. G. (1970). Characteristics of ruminococcus and cellulolytic butyrivibrio species from the rumens of sheep fed differently supplemented teff (Eragrostis tef) hay diets. Journal of General Microbiology 64, 1 1-17.

JoYNER, A. E. \& Baldwin, R. L. (1966). Enzymatic studies of pure cultures of rumen micro-organisms. Journal of Bacteriology 92, I 32 1-1330. 
KISTNER, A. \& Kotzé, J. P. (1973). Enzymes of intermediary metabolism of Butyrivibrio fibrisolvens and Ruminococcus albus grown under glucose limitation. Canadian Journal of Microbiology 19, 1119-1127.

Latham, M. J., Sharpe, M. E. \& Sutton, J. D. (1971). The microbial flora of the rumen of cows fed hay and high cereal rations and its relationship to the rumen fermentation. Journal of Applied Bacteriology 34, 425-434.

Latham, M. J., Storry, J. E. \& Sharpe, M. E. (1972). Effect of low-roughage diets on the microflora and lipid metabolism in the rumen. Applied Microbiology 24, 87I-877.

LuUngdahl, L. G. \& Wood, H. G. (I969). Total synthesis of acetate from $\mathrm{CO}_{2}$ by heterotrophic bacteria. Annual Review of Microbiology 23, 515-535.

Miller, T. L. (1975). Pyruvate cleavage reactions of $\mathbf{H}_{2}$ - and formate-producing rumen bacteria. Abstracts of the Annual Meeting of the American Society for Microbiology, abstract K20, p. 150. Washington: American Society for Microbiology.

RAMSEY, H. A. (1963). Separation of organic acids in blood by partition chromatography. Journal of Dairy Science 46, 480-483.

Roché, C. E. G., Albertyn, H., Gylswyx, N. O. van \& Kistner, A. (1973). The growth response of cellulolytic acetate-utilizing and acetate-producing butyrivibrios to volatile fatty acids and other nutrients. Journal of General Microbiology 78, 253-260.

Shane, B. S., Gouws, L. \& KISTNer, A. (1969). Cellulolytic bacteria occurring in the rumen of sheep conditioned to low-protein teff hay. Journal of General Microbiology 55, 445-457.

Thauer, R. K., Rupprecht, E. \& Jungermann, K. (1970). The synthesis of one-carbon units from $\mathrm{CO}_{2}$ via a new ferredoxin dependent monocarboxylic acid cycle. FEBS Letters 8, 304-307.

Weller, R. A., Gray, F. V., Pilgrim, A. F. \& Jones, G. B. (I967). The rates of production of volatile fatty acids in the rumen. IV. Individual and total volatile fatty acids. Australian Journal of Agricultural Research 18, 107-I 18 . 